\title{
MINAT MEMBACA PADA MAHASISWA PRODI PENDIDIKAN BAHASA JEPANG FKIP UNIVERSITAS RIAU
}

\author{
Nana Rahayu ${ }^{1}$, Sarah Azizah ${ }^{2}$ \\ 1,2 Universitas Riau, Pekanbaru, Indonesia \\ Inana.rahayu@lecturer.unri.ac.id, ${ }^{2}$ sarazizah30@gmail.com
}

\begin{abstract}
ABSTRAK
Penelitian ini bertujuan untuk mendeskripsikan seberapa besar minat membaca mahasiswa Program Studi Pendidikan Bahasa Jepang FKIP Universtias Riau terhadap bacaan berbahasa Jepang. Metode dalam penelitian ini menggunakan pendekatan kuantitatif dengan teknik pengambilan sampel menggunakan teknik sampel jenuh. Sampel penelitian adalah mahasiswa angkatan 2018 tahun ajaran 2020/2021 yang berjumlah 30 orang. Data minat membaca mahasiswa dikumpulkan melalui angket tertutup yang terdiri dari 30 item pernyataan dan diolah menggunakan bantuan IBM SPSS 25.0. Nilai terendah, tertinggi, rata-rata dan deviasi standar dihitung dengan statistik hipotetik untuk membantu pengaktegorian data yaitu kategori rendah, sedang dan tinggi. Hasil dari penelitian menunjukkan bahwa minat membaca mahasiswa angkatan 2018 terhadap bacaan berbahasa Jepang masuk ke dalam kategori sedang dengan persentase sebesar 76.7\%. Bacaan yang banyak disukai oleh mahasiswa adalah bacaan ringan seperti cerita rakyat atau dongeng anak-anak. Dengan demikian dapat disimpulkan bahwa semangat dan motivasi mahasiswa untuk membaca masih rendah sehingga mahasiswa belum memiliki perasaan dan sikap yang positif terhadap bacaan berbahasa Jepang.
\end{abstract}

Kata Kunci: mahasiswa, minat membaca, dokkai

\section{STUDENTS' READING INTERESTS AT JAPANESE LANGUAGE EDUCATION PROGRAM OF FKIP, UNIVERSITAS RIAU}

\section{ABSTRACT}

This study aimed to describe students' reading interest at the Japanese Language Education Program of FKIP, Universitas Riau through Japanese reading texts. The method of this study was a quantitative approach with a sampling technique using a saturated sample technique. The samples of this study were the students of the Japanese Language Education Program for the 2020/2021 academic year; the total number of respondents in this study was 30 students. The data were collected using the reading interest questionnaire consisting of 30 statement items. The data collected were analyzed through frequency analysis using SPSS 25.0. The lowest, highest, and the mean score and standard deviation values were calculated by using hypothetical statistics to help categorize data into low, medium, and high categories. The study results showed that asking students to read for Japanese reading is in the medium category with a percentage of $76.7 \%$. The readings mostly liked by students were light readings such as folk tales or children's fairy tales. To conclude, the students' reading enthusiasm and motivation were still so low that students did not have positive feelings and attitudes towards Japanese reading.

Keywords: students, reading interest, dokkai

\begin{tabular}{|c|c|c|}
\hline Submitted & Accepted & Published \\
\hline 25 Agustus 2021 & 29 Oktober 2021 & 24 November 2021 \\
\hline
\end{tabular}

\begin{tabular}{|l|l|ccc|}
\hline Citation & $:$ & Rahayu, N., \& Azizah, S. (2021). Minat Membaca Pada Mahasiswa Prodi Pendidikan Bahasa Jepang FKIP Universitas \\
& & Riau. Jurnal PAJAR (Pendidikan dan Pengajaran), & 5(6), \\
\hline http://dx.doi.org/10.33578/pjr.v5i6.8539. & 1582-1587. \\
\hline
\end{tabular}

\section{PENDAHULUAN}

Mempelajari bahasa Jepang sama halnya mempelajari bahasa asing lainnya menurut Nurgiyantoro (2001) pembelajar dituntut untuk mempelajari empat ketrampilan berbahasa Jepang, yaitu Choukai (menyimak), Kaiwa (berbicara), Dokkai (membaca) dan Sakubun (menulis). Begitu juga halnya di Program Studi Pendidikan Bahasa Jepang FKIP Universitas Riau. Matakuliah membaca diberikan kepada mahasiswa sejak semester satu hingga semester enam. Diharapkan mahasiswa yang belajar bahasa Jepang memiliki kemampuan membaca level N3 awal menurut standar yang ditetapkan oleh The Japan Foundation. Dari keempat ketrampilan berbahasa tersebut, pembelajaran membaca memiliki peran yang sangat besar dalam meningkatkan kemampuan berbahasa Jepang. Hal ini sejalan dengan pendapat pendapat Israel dan Duffy (2011) 
yang menyimpulkan bahawa pembelajaran membaca harus dipelajari terlebih dahulu sebelum mempelajari ketrampilan berbahasa lainnya.

Mata kuliah Dokkai yang diajarkan di Program Studi Pendidikan Bahasa Jepang FKIP Universitas Riau menuntut mahasiswa untuk mampu membaca sekaligus memahami bacaan berbahasa Jepang yang menggunakan huruf Kanji, Hiragana dan Katakana secara bersamaan. Dalam praktiknya, mahasiswa merasa kesulitan dalam mengikuti perkuliahan Dokkai. Dampaknya mahasiswa enggan mempelajarinya. Ragam kesulitan dalam belajar Dokkai memang relatif lebih banyak dibandingkan dengan belajar reading dalam bahasa Inggris misalnya. Membaca bacaan berbahasa Jepang diperlukan kemampuan tambahan yakni mampu membaca dan memahami arti huruf Kanji. Kanji adalah huruf yang dipelajari oleh mahasiswa selain huruf Hiragana dan Katakana yang digunakan oleh bangsa Jepang. Karakter Kanji berbeda dengan aksara lainnya seperti huruf Latin, Arab, atau Jawa yang pada umumnya hanya merupakan simbol bunyi. Huruf Kanji bukan sekedar simbol bunyi karena tiap guratan atau karakter juga mempunyai makna. Oleh karena itu jumlah huruf Kanji sangat banyak bahkan ribuan. Di luar permasalahan tulisan sebenarnya permasalahan dalam pembelajaran membaca pemahaman relatif sama dengan bahasa lainnya. Mata kuliah Dokkai ini sendiri dalam kurikulumnya memiliki capaian pembelajaran diantaranya mahasiswa dapat berkomunikasi baik secara lisan maupun tulisan dengan topik-topik sederhana dan familiar.

Untuk mendukung tercapainya capaian pembelajaran membaca dan mengembangkan kemampuan membaca mahasiswa dibutuhkan minat dan motivasi dari mahasiswa itu sendiri untuk terlibat dalam membaca bacaan berbahasa Jepang. Mahasiswa diberi kesempatan untuk berperan aktif dalam memilih tema dan topik bacaan (Macalister,2011). Minat mendorong mahasiswa untuk menentukan jenis bacaan bahasa Jepang yang akan dibaca dan menimbulkan kebiasaan untuk membaca bacaan tersebut di waktu luang. Kebiasaan ini dapat membantu mahasiswa membiasakan diri melihat huruf-huruf Jepang dan dengan otomatis akan menambah pengetahuan tentang budaya dan masyarakat Jepang.

Siswati (2010) dalam tulisannya menyebutkan bahwa kurangnya minat membaca pada mahasiswa juga dapat diketahui dari partisipasi mahasiswa tersebut dalam perkuliahan. Sikap enggan untuk bertanya jika menemui kesulitan kepada dosen juga memicu kurangnya minat mahasiswa mengikuti kuliah. Mahasiswa cenderung pasif untuk mengemukakan pendapat dikarenakan mereka tidak paham mengenai isi bacaan tersebut. Hal tersebut juga terjadi pada mahasiswa Program Studi Pendidikan Bahasa Jepang FKIP Universitas Riau. Mahasiswa yang mengikuti perkuliahan pada mata kuliah Dokkai lebih senang membaca bacaan berbahasa Jepang yang sederhana jika dibandingkan dengan bacaan yang ada pada materi perkuliahan dikarenakan kurangnya kemampuan kosakata. Sehingga jika diberi pertanyaan mahasiswa sulit untuk menjawab meskipun pertanyaan yang diberikan dapat ditelusuri dari bacaan yang sudah mereka baca. Hal tersebut sejalan dengan yang dijelaskan pada situs NHK World-Japan pada kolom tanya jawab bahwa untuk membaca bacaan berbahasa Jepang kita dituntut untuk terus membaca meskipun menemukan kata-kata yang tidak dimengerti. Membaca bacaan berbahasa Jepang, diantara kata-kata yang tidak dimengerti, ada beberapa kata yang tidak perlu diketahui memahami isi bacaan. Penting untuk menyelesaikan hingga akhir bacaan tanpa harus membuka kamus.

Materi bacaan yang digunakan pada mata kuliah Dokkai penting untuk diketahui oleh mahasiswa meskipun pada beberapa materinya tidak sejalan dengan keadaan mahasiswa sehingga mahasiswa kurang memahami apa yang disampaikan oleh bacaan tersebut. Permasalahan yang sering terjadi dalam proses belajar mengajar yang ditemui penulis adalah kurangnya aktivitas membaca yang menjadi materi dalam pembelajaran Dokkai. Oleh karena itu penelitian ini bertujuan untuk menjelaskan seberapa besar minat membaca mahasiswa Program Studi Pendidikan Bahasa Jepang FKIP Unviersitas Riau angkatan 2018 tahun ajaran 2020/2021 terhadap bacaan berbahasa Jepang. 


\section{KAJIAN TEORETIS}

Minat diartikan sebagai suatu rasa lebih suka dan rasa kecenderungan pada suatu hal atau suatu aktivitas tanpa ada yang menyuruh (Slameto, 2003). Selain itu, minat juga diartikan sebagai salah satu aspek psikis manusia yang menjadi pendorong untuk mencapai tujuan (Sudarsana, 2014). Minat dikonseptualisasikan sebagai kecenderungan yang relatif stabil yang berkembang seiring waktu dan dikaitkan dengan peningkatan nilai, pengetahuan, dan perasaan positif (Hidi, 2001). Kecenderungan ini disebabkan oleh beberapa faktor, antara lain sebagai berikut:

a) Faktor Internal. Faktor internal adalah sesuatu yang membuat seseorang berminat yang datangnya dari dalam diri. Maksudnya adalah minat akan dipengaruhi oleh kebutuhan dalam diri seseorang yang dapat bermanfaat secara langsung untuk kepuasan emosionalnya, seperti: perhatian, keingintahuan, motivasi, kebutuhan, dan lain sebagainya.

b) Faktor Eksternal. Faktor eksternal adalah sesuatu yang membuat seseorang berminat yang datangnya dari luar diri, seperti: dorongan dari orang tua.

c) Dorongan dari guru, rekan, tersedianya sarana dan prasarana atau fasilitas, dan keadaan lingkungan yang dapat memfasilitasi minat tertentu.

Minat membaca yang baik dapat membantu dalam memahami dan meningkatkan daya ingat pembaca dari bacaan yang telah dibaca seperti pesan yang hendak disampaikan oleh penulis melalui media kata-kata atau bahasa tulis. Kata-kata dalam bacaan diolah untuk mengkonstruksi makna dan pemahaman dengan memperhatikan keadaan, nilai, fungsi, dan dampak dari bacaan. Tujuan membaca berbeda untuk setiap individu, sesuai dengan kepentingannya masingmasing. Kendati pembaca mempunyai tujuan yang sama, tetapi tujuan dicapai dengan cara berbeda- beda. Kegiatan membaca tidak serta merta hanya melakukan kegiatan membaca pada apa yang tertulis dalam teks saja, tetapi dari kegiatan membaca tersebut harus mampu memahami isi yang terkandung yang disampaikan oleh penulis.

Membaca pemahaman dalam bahasa Jepang dikenal dengan istilah Dokkai. Dokkai tersusun dari dua karakter Kanji, yaitu doku (読), yang berarti 'membaca' dan kai (解) yang berarti 'memahami'. Dalam kamus Reikai Shinkokugojiten disebutkan "Dokkai: bunshou nado wo yonde, naiyou wo rikai suru koto" yang artinya Dokkai adalah aktifitas membaca dan memahami isi atau pesan dari materi tekstual. Dokkai bukan hanya proses mendapatkan informasi semata tetapi juga melibatkan proses interpretasi dan penilaian. Dokkai merupakan kegiatan membaca yang mencakup proses penguraian simbol, pemahaman inferensial, dan sampai pada pemantauan. Jadi, selain membaca kalimat-kalimat dalam bacaan berbahasa Jepang, mahasiswa dituntut untuk dapat memahami isi bacaan tersebut agar dapat menangkap pesan yang ingin disampaikan penulis sebagai wujud komunikasi. Kegiatan memahami bacaan akan sulit dilakukan apabila pembaca sulit berkonsentrasi yang disebabkan oleh kelelahan fisik dan mental atau sedang bosan, dan rendahnya motivasi terhadap kegiatan membaca. Begitu juga bagi mahasiswa, hal-hal tersebut dapat mempengaruhi kemampuan pemahaman mahasiswa dalam membaca, terlebih lagi jika bacaan yang dibaca merupakan bacaan bahasa asing seperti bahasa Jepang. Berdasarkan kurikulum yang tercatat dalam buku panduan mahasiswa Universitas Riau dalam perkuliahan bahasa Jepang keterampilan membaca diasah melalui mata kuliah Dokkai. Mata kuliah Dokkai bertujuan agar mahasiswa mampu mengerti dan memahami teks yang bacaan di dalamnya menyangkut arti dan penggunaan kosakata, pemahaman ungkapan, dan pola kaliimat serta pemahaman isi dari bacaan tersebut. Selain itu 
dalam mata kuliah Dokkai mahasiswa diajarkan untuk membaca wacana berbahasa Jepang dengan cepat dan tepat. Hal ini sangat diperlukan dalam mempraktikkan penggunaan bahasa Jepang dalam pekerjaan maupun pemakaian bahasa Jepang pada kehidupan sehari-hari. Selain itu membaca cepat dan tepat sangat diperlukan dalam mengikuti ujian kemampuan bahasa Jepang JLPT.

Dari penjelasan tersebut di atas, maka minat membaca bacaan berbahasa Jepang dapat diartikan sebagai perasaan senang yang mendorong atau memotivasi mahasiswa Program Studi Pendidikan Bahasa Jepang FKIP Universitas Riau angkatan 2018 untuk membaca tanpa paksaan dari pihak luar sehingga menimbulkan perasaan puas dalam membaca. Minat membaca memicu perasaan dan sikap yang positif terhadap informasi-informasi baru yang terdapat di dalam bacaan. Perasaan dan sikap yang positif tersebut secara tidak langsung memfasilitasi mahasiswa untuk menyediakan lebih banyak waktu, upaya, dan konsentrasi untuk membaca sehingga terjadinya peningkatan pemahaman dalam pembelajaran.

\section{METODE PENELITIAN}

Untuk mendeskripsikan minat membaca pada mahasiswa Program Studi Pendidikan Bahasa Jepang FKIP Universitas angkatan 2018 tahun ajaran 2020/2021 penulis menggunakan pendekatan kuantitatif dengan sampel penelitian seluruh mahasiswa semester enam yang mengikuti mata kuliah Dokkai dan Sakubun 5. Dalam hal ini dilakukan teknik sampling jenuh. Menurut Sugiyono (2011), sampling jenuh adalah teknik penentuan sampel bila semua anggota populasi digunakan sebagai sampel penelitian dengan tujuan untuk membuat generalisasi dengan kesalahan yang sangat kecil.
Penelitian diawali dengan studi kepustakaan untuk mencari bahan rujukan dan fokus penelitian. Setelah menentukan indikator minat membaca kemudia angket tertutup disebarkan melalui Google Form. Pada pengambilan data mahasiswa sebagai responden yang mengisi angket berjumlah 30 orang dari 34 mahasiswa. Angket yang digunakan berisi 30 pernyataan yang meliputi:

1. Adanya rasa senang terhadap kegiatan membaca bacaan berbahasa Jepang.

2. Kepuasan terhadap aktivitas membaca bacaan berbahasa Jepang.

3. Partisipasi aktif tanpa dipaksa untuk membaca bacaan berbahasa Jepang.

4. Lebih menyukai bacaan berbahasa Jepang dengan topik yang lebih sederhana untuk materi pada perkuliahan Dokkai.

Data angket kemudian diuji realibitas untuk dengan menggunakan teknik reliabilitas Alfa Cronbach karena instrumen menggunakan skala Likert yang memiliki skala lebih dari 1.Selanjutnya dilakukan uji statistik deskriptif untuk mengetahui minat membaca mahasiswa. Menurut Sugiyono (2011), statistik deskriptif adalah statistik yang digunakan untuk menganalisis data dengan cara mendeskripsikan atau menggambarkan data yang telah terkumpul sebagaimana adanya tanpa bermaksud membuat kesimpulan yang berlaku umum atau generalisasi.

\section{HASIL DAN PEMBAHASAN}

Setelah angket dikumpulkan dan dihitung realibilitasnya dengan menggunakan teknik Alfa Cronbach dimana angket dikatakan reliabel apabila koefisien reliabitas Alfa Cronbach lebih dari $0.06\left(\mathrm{r}_{\mathrm{xy}}>0.06\right)$. Koefisien reliabilitas yang diperoleh adalah sebesar 0,896 atau lebih besar dari $0.06\left(\mathrm{r}_{\mathrm{xy}}>0.06\right)$. Sehingga angket minat membaca dikatakan reliabel. Hasil uji reliabilitas dapat dilihat pada tabel berikut:

Tabel 1. Hasil Uji Reliabilitas Reliability Statistics

\begin{tabular}{lll}
\hline Cronbach's Alpha & N of Items & \\
\hline & .896 & 30 \\
\hline
\end{tabular}


Kemudian hasil perhitungan statistik hipotetik angket minat membaca adalah skor minimal yang diperoleh 30, dan skor tertinggi 149.5. Rata-rata yang diperoleh dari data adalah sebesar 98,7 dan standar deviasi sebesar 19.9. Hasil perhitungan statistik hipotetik angket minat membaca dapat dilihat pada tabel berikut:

Tabel 2. Hasil Hitung Statistik Hipotetik

\begin{tabular}{cccccc}
\hline Variable & $\boldsymbol{N}$ & $\begin{array}{c}\text { Minimal } \\
\text { Value }\end{array}$ & $\begin{array}{c}\text { Maximal } \\
\text { Value }\end{array}$ & Mean & $\begin{array}{c}\text { Std. } \\
\text { Deviation }\end{array}$ \\
\hline Minat Membaca & 30 & 30 & 149.5 & 98.7 & 19.9 \\
\hline
\end{tabular}

Hasil analisis statistik diketahui minat membaca mahasiswa yang berada dalam kategori rendah berjumlah 4 orang (13.3\%), dalam kategori sedang berjumlah 23 orang (76.7\%), dan kategori tinggi berjumlah 3 orang (10\%). Hasil tersebut dapat dilihat pada tabel berikut:

Tabel 3. Hasil Analisis Statistik Deskriptif Minat Membaca

\begin{tabular}{|c|c|c|c|c|c|}
\hline & & Frequency & Percent & $\begin{array}{c}\text { Valid } \\
\text { Percent }\end{array}$ & $\begin{array}{c}\text { Cumulative } \\
\text { Percent }\end{array}$ \\
\hline \multirow[t]{4}{*}{ Valid } & Rendah & 4 & 13.3 & 13.3 & 13.3 \\
\hline & Sedang & 23 & 76.7 & 76.7 & 90.0 \\
\hline & Tinggi & 3 & 10.0 & 10.0 & 100.0 \\
\hline & Total & 30 & 100.0 & 100.0 & \\
\hline
\end{tabular}

Dari perhitungan skor skala yang diperoleh dari tiap item pernyataan menyatakan bahwa saat membaca bacaan berbahasa Jepang mahasiswa Program Studi Pendidikan Bahasa Jepang FKIP Unviersitas Riau merasa senang dan puas jika dapat membaca beragam topik, mempelajari ungkapan-ungkapan baru, memahami pesan penulis, menemukan informasi baru, dan mempelajari tata bahasa (bunpou). Selain membaca bacaan berbahasa Jepang dengan kemauan sendiri, bagi mahasiswa sering membaca bacaan berbahasa Jepang akan memberikan pengaruh pada hasil latihan dan tes pada mata kuliah Dokkai. Hasil angket juga menyebutkan bahwa item bacaan berbahasa Jepang yang terlalu panjang kurang diminati oleh mahasiswa jika dibandingkan dengan bacaan yang lebih sederhana dan familiar seperti cerita rakyat Jepang atau dongeng anak-anak Jepang sebagai latihan membaca bacaan berbahasa Jepang.

Dalam membaca, minat memiliki peran yang sanagat penting karena minat memiliki peran memilah dan memproses informasi. Dengan adanya minat membaca maka akan menciptakan perasaan dan sikap yang positif terhadap bacaan sehingga dapat lebih memahami bacaan dan proses pembelajaran juga akan meningkat. Kategori sedang untuk minat membaca bacaan berbahasa Jepang pada mahasiswa Program Studi Pendidikan Bahasa Jepang angkatan 2018 dapat disebabkan oleh kebiasaan membaca mahasiswa yang hanya dilakukan ketika perkuliahan saja. Scott (dalam Siswati, 2010) mendefinisikan ketidakbiasaan membaca pada mahasiswa yang memiliki kemampuan membaca yang baik akan memilih untuk tidak membaca. Minat membaca tidak selalu berada pada kategori yang tinggi karena ada situasi-situasi tertentu yang dapat mempengaruhi minat membaca tersebut. Oleh karena itu, setelah mengetahui miant membaca bacaan berbahasa Jepang pada mahasiswa dirasa perlu untuk mengetahui faktor-faktor yang mempengaruhi minat membaca. Sehingga dosen mata kuliah Dokkai dapat menerapkan strategi atau metode yang cocok untuk meningkatkan minat membaca mahasiswa Program Studi Pendidikan Bahasa Jepang FKIP Universitas Riau. 


\section{SIMPULAN DAN REKOMENDASI}

Kebiasaan membaca merupakan hal penting yang dapat mempengaruhi minat membaca bacaan berbahasa Jepang pada mahasiswa Program Studi Pendidikan Bahasa Jepang FKIP Universitas Riau angkatan 2018 tahun ajaran 2020/2021. Kebiasaan membaca bacaan berbahasa Jepang yang baik akan terbentuk dengan sendirinya jika mahasiswa tersebut memiliki minat membaca. Berdasarkan hasil perhitungan statistik rata-rata minat baca dari 30 orang mahasiswa angkatan 2018 yang termasuk pada kategori sedang (76.7\%). Mahasiswa lebih senang jika tema bacaan lebih sederhana dan familiar dibandingkan dengan bacaan berbahasa Jepang yang panjang.

Oleh karena itu diharapkan kepada peneliti selanjutnya untuk dapat mengukur apakah minat membaca yang sedang dapat mempengaruhi kemampuan memahami bacaan berbahasa Jepang khususnya pada tes kemampuan berbahasa Jepang (JLPT). Sehingga pengajar dapat menggunakan strategi dan pemilihan materi bacaan berbahasa Jepang yang sesuai dengan kemampuan mahasiswa.

\section{DAFTAR PUSTAKA}

Hidi, S. ((2001). Interest, Reading, and Learning: Theoretical and Practical Consideration. Educational Psikology Review, 13(3), 191 208.

Israel, S. E, \& Duffy, G. G. (2009). Handbook of Research on Reading Comprehension. New York: Routledge. Pdf

NHK World - Japan https://www.nhk.or.jp/lesson/indonesian/q uestions/0012.html

Nurgiyantoro, B. (2001). Penilaian dalam Pembelajaran Bahasa dan Sastra. Yogya: BPFE-Yogyakarta.

Macalister, J. (2011). Today's Teaching, Tomorrow's Text: Exploring The Teaching of Reading. ELT Journal, 65(2), 161-169.

Setyowati, R. T., Purnomo, \& Sukardi. (2017). Hubungan Minat Baca dan Kebiasaan Membaca dengan Kemampuan Membaca Pemahaman. Joyful Learning Journal, 6 (2), 78-83.

\section{http://journal.unnes.ac.id/sju/indext.php/jl $\mathrm{j}$}

Siswati. (2010). Minat Membaca pada Mahasiswa (Studi Deskriptif pada Mahasiswa Fakultas Psikologi Undip Semester 1). Jurnal Psikologi Undip, 8(2).

Slameto. (2003). Belajar dan Faktor-faktor yang Mempengaruhinya. Jakarta: Rineka Cipta.

Sudarsana, U. (2004) Modul 1. Pembinaan Minat Baca. Jakarta: Universitas Terbuka. http://repository.ut.ac.id/4222/1/PUST442 1-M1.pdf

Sugiyono. (2011). Metode Penelitian Pendidikan. Bandung: ALFABETA. 